\title{
GAMBARAN TINGKAT KEPADATAN JENTIK NYAMUK AEDES AEGYPTI DI KELURAHAN KENALI ASAM BAWAH KOTA JAMBI.
}

\author{
Density Level Of Aedes Aegypti Mosquito Description in Kenali Asam Bawah District, \\ Jambi City.
}

\author{
Oka Lesmana $\mathbf{S}^{\mathbf{1}}$, Rd Halim ${ }^{2}$ \\ 1,2 Program Studi Ilmu Kesehatan Masyarakat Fakultas Kedokteran dan Ilmu Kesehatan Universitas \\ Jambi
}

\begin{abstract}
Abstrak
Secara global diperkirakan 50-100 juta orang di seluruh dunia terinfeksi DBD setiap tahunnya. Pada tahun 2017 jumlah penderita DBD di Indonesia yang dilaporkan sebanyak 68.407 kasus, jumlah kematian 493 orang, angka kesakitan (IR) 26,12 per 100.000 penduduk, dan angka kematian (CFR) 0,72\%. Salah satu indikator yang digunakan untuk pengendalian DBD yaitu angka bebas jentik (ABJ). ABJ secara nasional belum mencapai target program yang sebesar $\geq 95 \%$ sehingga perlu dilakukan pengamatan vektor pada stadium jentik untuk mengetahui penyebaran, kepadatan nyamuk, habitat utama jentik, dan dugaan resiko terjadinya penularan. Kepadatan populasi nyamuk Aedes aegypti dapat diketahui dengan melakukan survey jentik sehingga didapatkan angka House Index, Container Index, Bruteau Index, dan Density Figure. Penelitian ini adalah penelitian survey deskriptif dan menggunakan metode cross sectional yang memaparkan gambaran kepadatan dan jenis jentik berdasarkan rumah dan Tempat Penampungan Air (TPA) yang diperiksa. Sampel penelitian berjumlah 160 rumah. Teknik pengambilan sampel menggunakan proporsional random sampling. Hasil penelitian diketahui angka House Index 30\%, Container Index 19,5\%, dan Bruteau Index 74\% sehingga didapatkan Density Figure 5,3 yang berarti wilayah Kelurahan Kenali Asam Bawah termasuk Daerah Merah. Maka perlu kewaspadaan tinggi dan pengendalian segera karena derajat penularan penyakit yang dibawa vektor tinggi. Angka bebas jentik (ABJ) $70 \%$ jauh berada dibawah standar nasional 95\%. Saran peneliti agar pemerintah daerah, perangkat desa, dan masyarakat setempat bekerjasama untuk menggiatkan kegiatan pemberantasan sarang nyamuk (PSN) dan Gerakan Satu Rumah Satu Jumantik.
\end{abstract}

Kata Kunci: DBD, Jentik, Aedes aegypti

\begin{abstract}
It is estimated that 50-100 million people worldwide are infected with DHF every year. In 2017, the number of DHF sufferers in Indonesia was reported as many as 68,407 cases, the number of deaths was 493 people, the morbidity rate (IR) was 26.12 per 100,000 population, and the death rate (CFR) was $0.72 \%$. One of the indicators used to control dengue is the larva free index (ABJ). The larva free index in Indonesia has not yet reached the national target, which is $\geq 95 \%$, so it is necessary to carry out vector observations at the larva stage to determine the spread, mosquito density, main larvae habitat, and the suspected risk of transmission. The population density of the Aedes aegypti mosquito can be determined by conducting a larva survey to obtain the House Index, Container Index, Bruteau Index, and Density Figure numbers. This research is a descriptive survey research and uses a cross-sectional method that describes the density and type of larvae based on the house and water reservoir (TPA) examined. The research sample consisted of 160 houses. The sampling technique used proportional random sampling. The results showed that the number of House Index is 30\%, Container Index 19.5\%, and Bruteau Index 74\% so that the Density Figure 5.3 is obtained. This means that the area of Kenali Asam Bawah is included in the Red Area category. So it needs high vigilance and immediate control because the level of disease transmission carried by vectors is high. The larva free index (ABJ) of 70\% is far below the national standard of 95\%. Researchers suggest that local governments, village officials, and local communities work together to intensify mosquito nest eradication activities (PSN) and the "One Jumantik One Home" program.
\end{abstract}

Keywords: DHF, Larvae, Aedes aegypti

Korespondensi : Oka Lesmana S.

Email : okalesmana28@gmail.com 


\section{PENDAHULUAN}

Penyakit Demam Berdarah Dengue (DBD) merupakan masalah kesehatan di dunia terutama negara yang sedang berkembang, diperkirakan penyakit ini telah endemik pada lebih dari 100 negara, serta menginfeksi lebih dari 50 - 100 juta orang di dunia dan 500.000 kasus DBD memerlukan perawatan di rumah sakit dengan 22.000 kasus kematian setiap tahun. ${ }^{1} \quad$ Angka terjadinya kasus DBD mengalami peningkatan secara drastis diseluruh dunia dalam beberapa tahun terakhir. Lebih dari 2,5 milyar penduduk didunia, lebih dari $40 \%$ nya beresiko mengalami DBD. Diperkirakan 50-100 juta orang di seluruh dunia terinfeksi demam berdarah dengue setiap tahunnya. ${ }^{1}$

Indonesia sebagai salah satu negara tropis di dunia dengan kelembaban udara yang cukup tinggi menjadi pemicu berkembang biaknya nyamuk seperti Aedes aegypti yang merupakan salah satu vektor DBD, sehingga DBD mudah ditularkan melalui gigitan nyamuk Aedes aegypti. Hal tersebut menyebabkan masalah kesehatan karena terdapat banyak daerah endemik sehingga jumlah penderita semakin meningkat dan penyebaran pun semakin meluas ke wilayah lain dengan meningkatnya mobilitas dan kepadatan penduduk. $^{2}$ Dampak peningkatan penyebaran DBD dapat berpengaruh terhadap perekonomian, dikarenakan kehilangan waktu kerja, waktu pendidikan maupun biaya selama perawatan penderita DBD selama sakit, selain itu juga berdampak terhadap tingginya angka kesakitan dan meningkatkan resiko terjadinya kematian penderita DBD.

Pada tahun 2017 jumlah penderita DBD di Indonesia yang dilaporkan sebanyak 68.407 kasus, mengalami penurunan yang signifikan dari tahun 2016 sebanyak 204.171 kasus. Sedangkan jumlah kematian DBD tahun 2017 sebanyak 493 orang, juga mengalami penurunan dibandingkan tahun 2016 berjumlah 1.598 kematian. Angka kesakitan/Incidence Rate (IR) 26,12 per 100.000 penduduk tahun 2017 , sedangkan tahun 2016 IR 78,85 per 100.000 penduduk, dan CFR/angka kematian 0,72\% tahun 2017 dibandingkan dengan tahun 2016 CFR 0,83\%). ${ }^{3}$ Provinsi Jambi tahun 2017 secara statistik mampu menekan angka kasus DBD (IR) hingga menjadi 14,94 per 100.000, yang menempatkan Provinsi Jambi berada di atas target nasional. Namun kembali naik tahun 2018 menjadi IR 23,28 per 100.000 penduduk. Sedangkan Kota Jambi merupakan daerah endemik dengan jumlah kasus DBD tertinggi di Provinsi Jambi.

Menurut keterangan dari Dinas Kesehatan Kota Jambi, sepanjang tahun 2017 jumlah kasus DBD di Kota Jambi adalah sebanyak 567 kasus. Kasus DBD yang tertinggi di Kota Jambi berada di dua kecamatan yaitu Kecamatan Alam Barajo dan Kecamatan Kota Baru. Khususnya wilayah Kecamatan Kota Baru sepanjang tahun 2017 yaitu sebanyak 97 kasus, yang merupakan kasus tertinggi setelah Kecamatan Alam Barajo yaitu sebanyak 130 kasus. Terkhusus kasus DBD di Kecamatan Kota Baru tersebar di 5 kelurahan yaitu Paal V sebanyak 15 kasus, Sukakarya sebanyak 6 kasus, dan Simpang III Sipin sebanyak 28 kasus, yang merupakan wilayah kerja Puskesmas Paal V. Selanjutnya kelurahan Kenali Asam Atas sebanyak 12 kasus dan Kenali Asam Bawah sebanyak 36 kasus, yang merupakan wilayah kerja Puskesmas Paal X.

Seiring dengan semakin banyaknya kasus DBD, pemerintah membuat beberapa kebijakan terhadap pencegahan DBD yaitu dengan meningkatkan Sistem Kewaspadaan Dini (SKD) dan pengendalian vektor yang dilakukan dengan baik, terpadu dan berkesinambungan. Pengendalian vektor melalui surveilans vektor diatur dalam Kepmenkes No.581 tahun 1992, bahwa kegiatan pemberantasan sarang nyamuk (PSN) dilakukan secara periodik oleh masyarakat yang dikoordinir oleh RT/RW dalam bentuk PSN dengan menekankan kegiatan 3M plus (mengubur kaleng kaleng bekas, menguras tempat penampungan air secara teratur dan menutup tempat 
penyimpanan air dengan rapat serta penggunaan bubuk abate). Keberhasilan terhadap kegiatan PSN ini dapat diukur dengan Angka Bebas Jentik (ABJ). Apabila ABJ lebih atau sama dengan 95\% diharapkan penularan DBD dapat dicegah atau dikurangi.

Salah satu indikator yang digunakan untuk upaya pengendalian penyakit DBD yaitu angka bebas jentik (ABJ). Sampai tahun 2018, ABJ secara nasional belum mencapai target program yang sebesar $\geq$ $95 \%$. Oleh karena itu perlu dilakukan pengamatan vektor DBD pada stadium jentik untuk mengetahui penyebaran, kepadatan nyamuk, habitat utama jentik, dan dugaan resiko terjadinya penularan. Kepadatan populasi nyamuk Aedes aegypti dapat diketahui dengan melakukan survey jentik sehingga didapatkan angka House Index, Container Index, Bruteau Index, Density Figure dan ABJ sebagai indikator kepadatan jentik nyamuk Aedes aegypti. Maka peneliti tertarik untuk melakukan penelitian tentang gambaran tingkat kepadatan jentik nyamuk Aedes aegypti di Kelurahan Kenali Asam Bawah Kecamatan Kota Baru Kota Jambi.

\section{METODE PENELITIAN}

Dalam penelitian ini penulis menggunakan jenis penelitian deskriptif. Penelitian deskriptif ini untuk menilai dan mendeskripsikan tingkat kepadatan nyamuk Aedes aegypti dengan menghitung angka House Index (HI), Container Index (CI), Bruteau Index (BI), Density Figure (DF) dan Angka Bebas Jentik (ABJ) dengan melihat ada atau tidaknya larva di setiap tempat genangan air. Penelitian ini dilakukan di Kelurahan Kenali Asam Bawah, Kecamatan Kota Baru, Kota Jambi pada tahun 2017 hingga tahun 2018. Sampel penelitian berjumlah 160 rumah. Teknik pengambilan sampel menggunakan proporsional random sampling. Instrument penelitian antara lain: kuesioner, pedoman dan lembar observasi, serta peralatan untuk memeriksa jentik. Analisis univariat secara statistik digunakan untuk mengetahui distribusi frekuensi dari masing-masing variabel pada penelitian ini yaitu kondisi lingkungan rumah, jenis kontainer dan keberadaan jentik. Density Figure (DF) digunakan untuk melihat tingkat kepadatan jentik di suatu wilayah, dengan menggabungkan nilai $\mathrm{HI}, \mathrm{CI}$, dan BI.

\section{HASIL DAN PEMBAHASAN}

\section{A. Karakteristik Responden}

Hasil analisis univariat dapat dilihat karakteristik responden pada penelitian ini (Tabel 1). Berdasarkan (Tabel 1) di atas dapat dilihat bahwa responden sebagain besar adalah perempuan $(56,9 \%)$, untuk kelompok umur terbanyak adalah kelompok umur 35 - 44 Tahun (26,9\%), kelompok umur 45 - 54 Tahun $(23,1 \%)$ dan kelompok umur 24 - 34 Tahun (20,6\%). Untuk tingkat Pendidikan yaitu tingkat pendidikan terbanyak dari responden adalah tamat SMA $(40,6 \%)$, SMP $(18,1 \%)$ dan SD $(21,3 \%)$ sisanya Perguruan tinggi (15\%) dan tidak SD (5\%). Untuk jenis pekerjaan, yang terbanyak adalah tidak bekerja $(47,5 \%)$, sedangkan Buruh $(13,1 \%)$, Petani $(0,6 \%)$, Pedagang $(11,3 \%)$, Pegawai swasta (16,9\%), dan PNS $(10,6 \%)$.

\section{B. Kondisi Lingkungan dan Kontainer terhadap Keberadaan Jentik}

Hasil analisis dapat dilihat distribusi frekuensi kondisi lingkungan dan kontainer terhadap keberadaan jentik di lokasi penelitian (Tabel 2). Berdasarkan (Tabel 2) di atas dapat dilihat Keberadaan jentik nyamuk Aedes aegypti pada rumah responden yaitu 48 responden (30\%) rumahnya positif ditemukan jentik dan 112 rumah responden $(70 \%)$ tidak ditemukan jentik pada tempat penampungan airnya. Hasil pengamatan di setiap rumah responden untuk Letak kontainer air diperoleh hasil bahwa sebagian besar kontainer $109(68,9 \%)$ berada di dalam rumah dan sebanyak 51 (31,9\%) kontainer air berada di luar rumah. Hasil pengamatan di setiap rumah responden untuk $\mathrm{pH}$ air pada kontainer diperoleh hasil bahwa sebagian besar kontainer yaitu 137 (85,6\%) memiliki $\mathrm{pH}$ air normal yaitu $6-7,8$ dan 
sebanyak 23 kontainer $(14,4 \%)$ memiliki $\mathrm{pH}$ air tidak normal. Hasil pengamatan di setiap rumah responden untuk Suhu air pada kontainer diperoleh hasil bahwa sebagian besar kontainer $117(73,1 \%)$ suhu airnya baik adalah $27-30^{\circ} \mathrm{C}$ dan sebanyak $43(26,9 \%)$ suhu airnya pada kontainer kurang baik. Hasil pengamatan di setiap rumah responden untuk Suhu udara diperoleh hasil bahwa sebagian besar kontainer $117(73,1 \%)$ suhu udara baik yaitu $20-30^{\circ} \mathrm{C}$ dan sebanyak $43(26,9 \%)$ suhu udara tidak baik. Hasil pengamatan di rumah responden untuk Kelembaban kontainer diperoleh bahwa kontainer yang memiliki kelembapan yang baik hanya sebanyak $13(8,1 \%)$ dan sebagian besar kontainer $147(91,9 \%)$ adalah memiliki kelembapan kurang baik. Selanjutnya untuk hasil pengamatan Kondisi fisik kontainer diketahui bahwa 137 (85,6\%) kontainer memiliki kondisi fisik yang baik dan 23 $(14,4 \%)$ memiliki kondisi kurang baik.
Suhu optimum rata-rata pertumbuhan nyamuk antara $25^{\circ} \mathrm{C}-27^{\circ} \mathrm{C}$, pertumbuhan nyamuk akan terhenti sama sekali pada suhu kurang dari $10^{\circ} \mathrm{C}$ atau lebih dari $40^{\circ} \mathrm{C}$, untuk proses pertumbuhan jentik memerlukan suhu antara $25^{\circ} \mathrm{C}-30^{\circ} \mathrm{C}$, sementara berdasarkan aspek kelembaban udara, merupakan faktor penting dalam pertumbuhan nyamuk. Kelembaban optimal yang diperlukan untuk pertumbuhan nyamuk antara $60 \%$ sampai $80 \% .^{4}$ Berdasarkan hasil penelitian bahwa suhu udara di beberapa titik lokasi pemeriksaan jentik sebagian besar berkisar antara $20-30^{\circ} \mathrm{C}$, yang artinya kondisi suhu di lokasi sangat mendukung pertumbuhan nyamuk Aedes aegypti. Begitu juga dengan kelembapan udara di beberapa titik lokasi yang pemeriksaan jentik sebagian besar berada dibawah angka $81,5 \%$, yang berarti kelembapan di lokasi penelitian sangat mendukung pertumbuhan nyamuk Aedes aegypti.

\section{Tabel 1. Karakteristik Responden Berdasarkan Jenis Kelamin, Kelomok} Umur, Pendidikan dan Pekerjaan di Kelurahan Kenali Asam Bawah

\begin{tabular}{lcc}
\hline Variabel & $\begin{array}{c}\text { Frekuensi } \\
\mathbf{N}=\mathbf{1 6 0}\end{array}$ & $\begin{array}{c}\text { Persentase } \\
(\mathbf{\%})\end{array}$ \\
\hline Jenis Kelamin & 69 & 43,1 \\
\hline Laki-Laki & 91 & 56,9 \\
\hline Perempuan & & \\
\hline Kelompok Umur & 14 & 8,8 \\
\hline$<23$ Tahun & 33 & 20,6 \\
\hline 24-34 Tahun & 43 & 26,9 \\
\hline 35- 44 Tahun & 37 & 23,1 \\
\hline 45 -54 Tahun & 22 & 13,8 \\
\hline 55-64 Tahun & 11 & 6,9 \\
\hline$>$ 65 Tahun & & \\
\hline Pendidikan & 8 & 5,0 \\
\hline Tidak SD/Tamat & 34 & 21,3 \\
\hline Tamat SD & 29 & 18,1 \\
\hline Tamat SMP & 65 & 40,6 \\
\hline Tamat SMA & 24 & 15,0 \\
\hline Perguruan Tinggi & & \\
\hline Pekerjaan & 21 & 13,1 \\
\hline Buruh & 1 & 0,6 \\
\hline Petani & 18 & 11,3 \\
\hline Pedagang & 27 & 16,9 \\
\hline Pegawai Swasta & 17 & 10,6 \\
\hline PNS & 76 & 47,5 \\
\hline Tidak Bekerja & &
\end{tabular}


Tabel 2. Distribusi Frekuensi Kondisi Lingkungan pada Kontainer terhadap Keberadaan Jentik Nyamuk Aedes aegypti di Kelurahan Kenali Asam Bawah.

\begin{tabular}{lcc}
\hline \multicolumn{1}{c}{ Variabel } & $\begin{array}{c}\text { Frekuensi } \\
\mathbf{N = 1 6 0}\end{array}$ & $\begin{array}{c}\text { Persentase } \\
(\mathbf{\%})\end{array}$ \\
\hline Keberadaan Jentik & 48 & 30,0 \\
\hline Ada & 112 & 70,0 \\
\hline Tidak ada & & \\
\hline Ph Air & 23 & 14,4 \\
\hline Tidak normal $(<6$ dan $>7,8)$ & 137 & 85,6 \\
\hline Normal $(6-7,8)$ & & \\
\hline Suhu Air & 43 & 26,9 \\
\hline $\begin{array}{l}\text { Kurang baik }(<27 \text { dan } \\
\left.>30^{\circ} \mathrm{C}\right)\end{array}$ & & \\
\hline Baik $\left(27-30^{\circ} \mathrm{C}\right)$ & 117 & 73,1 \\
\hline Suhu Udara & 43 & \\
\hline $\begin{array}{l}\text { Kurang baik }(<20 \text { dan } \\
\left.>30^{\circ} \mathrm{C}\right)\end{array}$ & & \\
\hline Baik $\left(20-30^{\circ} \mathrm{C}\right)$ & 117 & 73,1 \\
\hline Kelembaban & 147 & \\
\hline $\begin{array}{l}\text { Kurang baik }(<81,5 \text { dan } \\
>89,5 \%)\end{array}$ & 13 & 8,1 \\
\hline Baik $(81,5-89,5 \%)$ & 23 & 14,4 \\
\hline Kondisi Kontainer & 137 & 85,6 \\
\hline Kurang baik & & \\
\hline Baik & & \\
\hline
\end{tabular}

Berdasarkan (Tabel 2) di atas dapat dilihat Keberadaan jentik nyamuk Aedes aegypti pada rumah responden yaitu 48 responden $(30 \%)$ rumahnya positif ditemukan jentik dan 112 rumah responden $(70 \%)$ tidak ditemukan jentik pada tempat penampungan airnya. Hasil pengamatan di setiap rumah responden untuk Letak kontainer air diperoleh hasil bahwa sebagian besar kontainer 109 $(68,9 \%)$ berada di dalam rumah dan sebanyak $51 \quad(31,9 \%)$ kontainer air berada di luar rumah. Hasil pengamatan di setiap rumah responden untuk $\mathrm{pH}$ air pada kontainer diperoleh hasil bahwa sebagian besar kontainer yaitu 137 $(85,6 \%)$ memiliki $\mathrm{pH}$ air normal yaitu 6 $-7,8$ dan sebanyak 23 kontainer $(14,4 \%)$ memiliki $\mathrm{pH}$ air tidak normal. Hasil pengamatan di setiap rumah responden untuk Suhu air pada kontainer diperoleh hasil bahwa sebagian besar kontainer
$117(73,1 \%)$ suhu airnya baik adalah 27 $-30^{\circ} \mathrm{C}$ dan sebanyak $43(26,9 \%)$ suhu airnya pada kontainer kurang baik. Hasil pengamatan di setiap rumah responden untuk Suhu udara diperoleh hasil bahwa sebagian besar kontainer $117(73,1 \%)$ suhu udara baik yaitu $20-30^{\circ} \mathrm{C}$ dan sebanyak $43(26,9 \%)$ suhu udara tidak baik. Hasil pengamatan di rumah responden untuk Kelembaban kontainer diperoleh bahwa kontainer yang memiliki kelembapan yang baik hanya sebanyak $13(8,1 \%)$ dan sebagian besar kontainer 147 (91,9\%) adalah memiliki kelembapan kurang baik. Selanjutnya untuk hasil pengamatan Kondisi fisik kontainer diketahui bahwa 137 (85,6\%) kontainer memiliki kondisi fisik yang baik dan $23(14,4 \%)$ memiliki kondisi kurang baik.

Suhu optimum rata-rata pertumbuhan nyamuk antara $25^{\circ} \mathrm{C}$ - 
$27^{\circ} \mathrm{C}$, pertumbuhan nyamuk akan terhenti sama sekali pada suhu kurang dari $10^{\circ} \mathrm{C}$ atau lebih dari $40^{\circ} \mathrm{C}$, untuk proses pertumbuhan jentik memerlukan suhu antara $25^{\circ} \mathrm{C}-30^{\circ} \mathrm{C}$, sementara berdasarkan aspek kelembaban udara, merupakan faktor penting dalam pertumbuhan nyamuk. Kelembaban optimal yang diperlukan untuk pertumbuhan nyamuk antara $60 \%$ sampai 80\%. ${ }^{4}$ Berdasarkan hasil penelitian bahwa suhu udara di beberapa titik lokasi pemeriksaan jentik sebagian besar berkisar antara $20-30^{\circ} \mathrm{C}$, yang artinya kondisi suhu di lokasi sangat mendukung pertumbuhan nyamuk
Aedes aegypti. Begitu juga dengan kelembapan udara di beberapa titik lokasi yang pemeriksaan jentik sebagian besar berada dibawah angka 81,5\%, yang berarti kelembapan di lokasi penelitian sangat mendukung pertumbuhan nyamuk Aedes aegypti.

\section{Keberadaan Jentik berdasarkan Jenis Kontainer}

Hasil analisis dapat dilihat distribusi frekuensi keberadaan jentik nyamuk Aedes aegypti berdasarkan jenis kontainer di Kelurahan Kenali Asam Bawah (Tabel 3).

\section{Tabel 3. Distribusi Frekuensi Keberadaan Jentik berdasarkan Jenis Kontainer di Kelurahan Kenali Asam Bawah.}

\begin{tabular}{lcccccc}
\hline \multirow{2}{*}{ Variabel } & \multicolumn{2}{c}{ Jentik } & Jumlah & \% \\
\cline { 2 - 5 } & Ada & \% & Tidak ada & \% & & \\
\hline Akuarium & 1 & 1,4 & 3 & 1,0 & 4 & $1,1 \%$ \\
\hline Bak Air & 6 & 8,1 & 2 & 0,7 & 8 & $2,1 \%$ \\
\hline Bak Mandi & 13 & 17,6 & 80 & 26,1 & 93 & $24,5 \%$ \\
\hline Dispenser & 0 & 0,0 & 18 & 5,9 & 18 & $4,7 \%$ \\
\hline Drum & 28 & 37,8 & 54 & 17,6 & 82 & $21,6 \%$ \\
\hline Ember & 11 & 14,9 & 113 & 36,9 & 124 & $32,6 \%$ \\
\hline Galon & 0 & 0,0 & 1 & 0,3 & 1 & $0,3 \%$ \\
\hline Got & 0 & 0,0 & 1 & 0,3 & 1 & $0,3 \%$ \\
\hline Kolam ikan & 7 & 9,5 & 3 & 1,0 & 10 & $2,6 \%$ \\
\hline Pot bunga & 1 & 1,4 & 2 & 0,7 & 3 & $0,8 \%$ \\
\hline Sumur & 0 & 0,0 & 19 & 6,2 & 19 & $5,0 \%$ \\
\hline Tempat makan burung & 2 & 2,7 & 4 & 1,3 & 6 & $1,6 \%$ \\
\hline Tower & 5 & 6,8 & 6 & 2,0 & 11 & $2,9 \%$ \\
\hline Jumlah & $\mathbf{7 4}$ & 100,0 & $\mathbf{3 0 6}$ & 100,0 & $\mathbf{3 8 0}$ & $\mathbf{1 0 0 \%}$ \\
\hline & & & & &
\end{tabular}

Berdasarkan (Tabel 3) menunjukan bahwa jumlah total kontainer yang diperiksa sebanyak 380 kontainer. Jenis kontainer terbanyak yang ditemukan (+) jentik nyamuk Aedes aegypti adalah Drum yaitu 28 Drum responden $(+)$ jentik atau $37,8 \%$ dari total 74 kontainer yang $(+)$ jentik. Jenis kontainer lainnya yang $(+)$ jentik seperti: akuarium (1), bak air (1), bak mandi 
(13), ember (11), kolam ikan (7), pot bunga (1), tempat makan burung (2), tower air (5). Sedangkan jenis kontainer yang tidak ditemukan jentik yaitu dispenser, gallon, got, dan sumur.

Penelitian sebelumnya oleh $\mathrm{Rd}$ Halim (2017) menyatakan bahwa pengontrolan tempat-tempat penampungan air utama seperti drum air, bak mandi, dan WC perlu dilakukan pengurasan secara berkala. Dalam melakukan pengurasan tempat penampungan air harus diperhatikan cara penyikatan dinding bak bagian karena biasanya terdapat kemungkinan adanya telur-telur nyamuk Aedes aegypti yang melekat. $^{8}$

Upaya pengawasan terhadap peralatan rumah tangga yang memiliki potensi sebagai tempat perindukan nyamuk seperti dispenser dan lemari pendingin perlu mendapat perhatian khusus dikarenakan pemilik terkadang tidak terlalu memperhatikan. Tempat penampungan air sisa pada dispenser dan tempat pembuangan air yang terdapat di belakang lemari pendingin tidak dibuang kemudian menjadi tempat perkembangbiakan jentik nyamuk Aedes spp. ${ }^{9}$

Selain tempat penampungan air yang terdapat didalam rumah, vas/pot bunga, kaleng dan botol bekas yang terletak diluar rumah juga berpotensi menjadi habitat jentik nyamuk Aedes spp. Keberadaan vas/pot bunga khususnya tanaman hias yang menggunakan air sebagai media pertumbuhan bisa berpotensi sebagai habitat jentik nyamuk Aedes spp. ${ }^{11}$

\section{House Index (HI)}

House Index merupakan jumlah rumah yang positif jentik dari semua rumah responden yang diperiksa. HI lebih menggambarkan luasnya penyebaran nyamuk di suatu wilayah. Berdasarkan (Tabel 2) di atas dapat dikatakan dari 160 rumah responden yang diperiksa adalah 48 rumah (+) ditemukan jentik dan 112 rumah (-) tidak ditemukan jentik.

Berdasarkan rumus HI dibawah ini:

$$
H I=\frac{\text { Jumlah rumah yang positif jentik }}{\text { Jumlah rumah yang diperiksa }} \times 100 \%
$$

Sehingga hasil yang didapatkan:

$$
H I=\frac{48}{160} \times 100 \%=30 \%
$$

Menurut WHO (2005), nilai standar HI adalah <10\%. Hal ini menandakan bahwa nilai $\mathrm{HI}$ di Kelurahan Kenali Asam Bawah sudah melewati standar yang ditetapkan oleh WHO sehingga rumah-rumah yang ada di kelurahan tersebut berpotensi besar menjadi tempat perkembangbiakan jentik nyamuk Aedes aegypti. ${ }^{5}$

\section{E. Container Index (CI)}

Container Index merupakan jumlah kontainer yang positif jentik dari semua kontainer yang diperiksa di lokasi penelitian. CI menunjukkan bahwa terdapat container sebagai tempat perkembangbiakan larva Aedes aegypti. Berdasarkan (Tabel 3) di atas dapat dikatakan dari 380 kontainer diperiksa, 74 kontainer $(+)$ ditemukan jentik dan 306 kontainer tidak ditemukan jentik.

Berdasarkan rumus CI dibawah ini:

$$
C I=\frac{\text { Jumlah kontainer yang positif jentik }}{\text { Jumlah kontainer yang diperiksa }} \times 100 \%
$$

Sehingga hasil yang didapatkan:

$$
C I=\frac{74}{380} \times 100 \%=19,5 \%
$$

Menurut WHO dalam Ramadhani dan Astuty (2013), nilai standar untuk Container Index (CI) adalah $<5 \%$. Sedangkan nilai CI di lokasi penelitian sudah melewati standar tang telah ditetapkan WHO. Hal ini menandakan 
bahwa penyebaran jentik nyamuk Aedes aegypti yang terdapat di dalam kontainer di Kelurahan Kenali Asam Bawah sudah melewati standar sehingga perlu dilakukan tindakan 3M Plus yaitu menguras tempat penampungan air, menutup tempat penampungan air, dan memanfaatkan kembali atau medaur ulang serta Plus yaitu memelihara ikan pemakan jentik nyamuk, menggunakan obat anti nyamuk, memasang kawat kasa pada ventilasi, gotong royong membersihkan lingkungan, periksa tempat penampungan air, meletakkan pakaian bekas pakai dalam wadah tertutup, memberikan larvasida pada penampungan air yang susah dikuras, memperbaiki saluran dan talang air yang tidak lancar, dan menanam tanaman pengusir nyamuk. ${ }^{6}$

\section{F. Breteau Index (BI)}

Breteau Index merupakan jumlah kontainer yang positif jentik dari 100 rumah yang diperiksa. BI menggambarkan kepadatan dan penyebaran vector pada suatu wilayah. Berdasarkan Tabel 3 di atas dapat dilihat jumlah kontainer (+) ditemukan jentik yaitu 74 kontainer dari 380 kontainer yang diperiksa.

Berdasarkan rumus BI dibawah ini:

$$
B I=\frac{J u m l a h \text { kontainer yang positif jentik }}{100 \text { rumah yang diperiksa }} \times 100 \%
$$

Sehingga hasil yang didapatkan:

$$
B I=\frac{74}{100} \times 100 \%=74 \%
$$

Menurut WHO (2005), nilai standar untuk Breteau Index (BI) adalah $<50 \%{ }^{5}$ Sedangkan nilai BI di lokasi penelitian sudah melewati standar yang telah ditetapkan WHO. Hal ini menandakan kepadatan dan penyebaran vektor nyamuk Aedes aegypti sudah tinggi di Kelurahan Kenali Asam Bawah sehingga perlu peningkatan kewaspadaan masyarakat terhadap penyebaran jentik nyamuk Aedes aegypti dengan cara seluruh masyarakat ikut berpartisipasi mandiri atau membuat gerakan masyarakat untuk melakukan pemeriksaan jentik nyamuk secara berkala serta melaporkan ke penanggungjawab daerah jika ditemukan ataupun tidak ditemukan jentik nyamuk Aedes aegypti juga secara berkala.

\section{G. Density Figure (DF)}

Analisa kepadatan populasi jentik nyamuk pada suatu daerah (DF) memiliki 3 kriteria yaitu Angka Density Figure berada pada rentang angka 1-3 maka daerah tersebut di nyatakan sebagai Daerah Hijau yaitu derajat penularan penyakit yang dibawa oleh vektor rendah atau tidak menularkan, Angka Density Figure berada pada rentang angka 4-5 maka daerah tersebut dinyatakan sebagai Daerah Kuning yaitu derajat penularan penyakit yang dibawa oleh vektor sedang atau perlu waspada, dan jika Angka Density Figure lebih dari 5 maka daerah tersebut dinyatakan sebagai Daerah Merah yaitu derajat penularan penyakit yang dibawa oleh vektor tinggi sehingga diperlukan pengendalian segera. ${ }^{7}$ 
Tabel 4. Kriteria Kepadatan (Density Figure) Jentik Nyamuk

\begin{tabular}{|c|c|c|c|c|}
\hline $\begin{array}{c}\text { Kriteria Kepadat } \\
\text { an }\end{array}$ & Density Figure (DF) & House Index (HI) & Container Index (CI) & Breteau Index (BI) \\
\hline Rendah & 1 & $1-3$ & $1-2$ & $1-4$ \\
\hline \multirow[t]{4}{*}{ Sedang } & 2 & $4-7$ & $3-5$ & $5-9$ \\
\hline & 3 & $8-17$ & $6-9$ & $10-19$ \\
\hline & 4 & $18-28$ & $10-14$ & $20-34$ \\
\hline & 5 & $29-37$ & $15-20$ & $35-49$ \\
\hline \multirow[t]{4}{*}{ Tinggi } & 6 & $38-49$ & $21-27$ & $50-74$ \\
\hline & 7 & $50-59$ & $28-31$ & $75-99$ \\
\hline & 8 & $60-76$ & $32-40$ & $100-199$ \\
\hline & 9 & $\geq 77$ & $\geq 41$ & $\geq 200$ \\
\hline
\end{tabular}

Sumber: WHO, 1973 dalam Pratama dan Aryasih, 2019.

Dari hasil perhitungan yang didapatkan dari gabungan $\mathrm{HI}, \mathrm{CI}$, dan $\mathrm{BI}$ maka tingkat kepadatan jentik nyamuk yang diperoleh berdasarkan Density Figure (Tabel 4) dapat dilihat di bawah ini:

1. House Index (HI) sebesar $30 \%$ pada posisi DF 5

2. Container Index (CI) sebesar 19,5\% pada posisi DF 5

3. Breteau Index (BI) sebesar $74 \%$ pada posisi DF6

Density Figure $(D F)=\frac{5+5+6}{3}=5,3$

Berdasarkan hasil perhitungan DF di atas maka dapat dilihat nilai DF di Kelurahan Kenali Asam Bawah yaitu lebih besar dari 5. Hal ini berarti Kelurahan Kenali Asam Bawah masuk kategori Daerah Merah yaitu derajat penularan penyakit yang dibawa vektor tinggi sehingga perlu tindakan pengendalian segera.

\section{H. Angka Bebas Jentik (ABJ)}

Hasil pengamatan terhadap 160 rumah responden (Tabel 2) di Kelurahan Kenali Asam Bawah didapatkan rumah yang positif ditemukan jentik adalah sebesar $30 \%$ dari jumlah rumah responden.

Berdasarkan rumus $\mathrm{ABJ}$ dibawah ini:

$$
A B J=\frac{\text { Jumlah rumah yang tidak ditemukan jentik }}{\text { jumlah rumah yang diperiksa }} \times 100 \%
$$

Sehingga hasil yang didapatkan:

$$
A B J=\frac{112}{160} \times 100 \%=70 \%
$$

Dalam menentukan status bebas DBD di dalam suatu wilayah adalah menggunakan Indikator $\mathrm{ABJ}$. ABJ dapat dikatakan baik jika nilai tersebut melebihi standar $95 \%$ dari total rumah yang diperiksa (Permenkes RI, 2017). ABJ sendiri merupakan gabungan antara HI (House Index), CI (Container Index), BI (Breteau Index) sehingga dapat diketahui nilai dari masing-masing berdasarkan rumah, kontainer dan keduanya. Berdasarkan perhitungan ABJ di atas diketahui nilai ABJ di Kelurahan Kenali Asam Bawah adalah 70\%, yang menandakan bahwa nilai ABJ dibawah standar nasional atau kepadatan jentik nyamuk masih tinggi serta berisiko mempercepat penularan penyakit DBD oleh vektor nyamuk Aedes aegypti di wilayah tersebut.

Kepadatan jentik nyamuk Aedes aegypti di suatu wilayah harus dikontrol dan dengan penanganan yang tepat dengan melakukan pemutusan rantai penularan melalui pemetaan vektor, dan mengendalikan populasi vektor DBD. ${ }^{10}$ Pemetaan (survei) vektor nyamuk Aedes aegypti merupakan dasar untuk mengendalikan populasi vektor DBD. Survei vektor berguna untuk menentukan distribusi, habitat utama vektor, densitas populasi dan tingkat 
kerentanan vektor terhadap insektisida.

\section{KESIMPULAN DAN SARAN}

Berdasarkan hasil dan pembahasan di atas maka dapat disimpulkan kepadatan jentik nyamuk Aedes aegypti di Kelurahan Kenali Asam Bawah yaitu berdasarkan House Index (HI) sebanyak $30 \%$ dari 160 rumah diperiksa, berdasarkan Container Index (CI) sebanyak 19,5\% dari 380 kontainer diperiksa, dan berdasarkan Bruteau Index (BI) sebanyak 74\% dari 160 rumah diperiksa sehingga didapatkan Density Figure di Kelurahan Kenali Asam Bawah sebesar 5,3 yang berarti masuk kategori daerah Merah dan perlu pengendalian segera. Saran oleh peneliti bagi masyarakat adalah berperan aktif dalam melakukan 3M Plus di lingkungan tempat tinggal dan Gerakan Satu Rumah Satu Jumantik yang sudah dibentuk oleh perangkat Desa perlu didukung dan dimotivasi oleh masyarakat juga agar Pemeriksaan Jentik Berkala dan Pemberantasan Sarang Nyamuk dapat terlaksana secara efektif dan efisien. Bagi pemerintah daerah agar mengawasi dan mendampingi upaya PJB dan PSN di masyarakat dan bila perlu dibentuk klinik sanitasi di Puskesmas sehingga masyarakat dapat berkonsultasi secara langsung dengan petugas kesehatan lingkungan.

\section{DAFTAR PUSTAKA}

1. Cruz, M.R., Sprinz, E., Rosset, I., Goldani, L., Teixeira, M.G., 2010. Dengue and Primeri Care : a tale of two cities. Bulletin of WHO. (88):244.

2. Widoyono. 2008. Penyakit Tropis; Epidemiologi, Penularan, Pencegahan \& Pemberantasannya. Jakarta : Erlangga.

3. Pusat Data dan Informasi Kementerian Kesehatan RI. 2018. Situasi Penyakit Demam Berdarah di Indonesia Tahun 2017. Jakarta: Ditjen P2P Kemenkes RI.

4. Purbowarsito, H. 2011. Uji bakteriologis air sumur di Kecamatan Semampir Surabaya. Tesis. Program Pascasarjana, Universitas Airlangga, Surabaya.

5. WHO. 2005. Panduan Lengkap Pencegahan dan Pengendalian Dengue dan Demam Berdarah Dengue. Jakarta: EGC.

6. Ramadhani, M.M. dan H. Astuty. 2013. Kepadatan dan penyebaran Aedes aegypti setelah penyuluhan DBD di kelurahan Paseban, Jakarta Pusat. Fakultas Kedokteran Universitas Indonesia, Jakarta. eJKI. 1(1).10-14.

7. Pratama, I Gede Octa Putra dan Aryasih, I Gusti Ayu Made. 2019. Gambaran tingkat kepadatan jentik nyamuk Aedes aegypti di wilayah kerja unit pelaksana teknis Kesmas Sukawati I Tahun 2019. Jurnal Kesehatan Lingkungan Vol.9 No.2 (171-178).

8. Halim, Rd. 2017. Hubungan Kondisi Lingkungan dan Kontainer dengan Keberadaan Jentik Nyamuk Aedes aegypti di Daerah Endemis Demam Berdarah Dengue (DBD) Kelurahan Kenali Asam Bawah Kota Jambi Tahun 2017 (Laporan Penelitian). Jambi: LPPM Universitas Jambi.

9. Farida, Athaillah dkk. 2019. Kepadatan Jentik Nyamuk Aedes aegypti di Gampong Peurada Kecamatan Syiah Kuala Kota Banda Aceh. JIMVET EISSN:2540-9492 Vol 3 (4): 224231

10. Fathi., S. Keman, dan C. U. Wahyuni. 2005. Peran faktor lingkungan dan perilaku terhadap penularan demam berdarah dengue di Kota Mataram. Jurnal Kesehatan Lingkungan. 2(1):1-10 
11. Budiyanto, A. 2013. Perbedaan warna kontainer berkaitan dengan keberadaan jentik Aedes aegypti di sekolah dasar. Loka Litbang P2B2 Baturaja. Jurnal Biotek Medisiana Indonesia. 1(2):65-71 